\title{
The Effect of an Extract From Ganoderma Lucidum (Reishi) on the Labeling of Blood Constituents with Technetium-99m and on the Survival of Escherichia Coli
}

\author{
Raquel Terra Agostinho ${ }^{1,2}$, Sebastião David Santos-Filho ${ }^{2}$, Adenilson de Souza da \\ Fonseca $^{2,3^{*}}$, Sotiris Missailidis ${ }^{4}$ and Mario Bernardo-Filho ${ }^{2}$ \\ ${ }^{I}$ Universidade Federal do Rio Grande do Norte; Av. General Gustavo Cordeiro de Farias, s/n; 59010180; Natal - \\ $R N$ - Brasil. ${ }^{2}$ Universidade do Rio de Janeiro; Instituto de Biologia Roberto Alcantara Gomes; Departamento de \\ Biofísica e Biometria; Av. 28 de Setembro, 87; 20551030; Rio de Janeiro - RJ - Brasil. ${ }^{3}$ Centro Universitário Serra \\ dos Órgãos; Centro de Ciências da Saúde; Av. Alberto Torres, 111; 25964004; Teresópolis - RJ - Brasil. \\ ${ }^{4}$ Department of Chemistry and Analytical Sciences; The Open University; Walton Hall; Milton Keynes; MK6 7AA; \\ U.K
}

\begin{abstract}
This study evaluated effects of an aqueous extract of Ganoderma lucidum (reishi) on the labeling of blood constituents with technetium- $99 m\left({ }^{99 m} T c\right)$ and on the survival of cultures of Escherichia coli treated with stannous chloride. Blood samples from Wistar rats were treated with reishi extract, radiolabeling procedure was performed, plasma $(P)$, blood cells $(B C)$ and insoluble $(I F)$ and soluble $(S F)$ fractions of $P$ and $B C$ were separated. The radioactivity was counted for the determination of the percentages of radioactivity (\%ATI). Cultures of Escherichia coli $A B 1157$ were treated with stannous chloride in the presence and absence of reishi extract. Blood samples and bacterial cultures treated with $\mathrm{NaCl} 0.9 \%$ were used as controls. Data indicated that reishi extract altered significantly $(p<0.05)$ the \%ATI of $P, B C, I F-P, S F-P, I F-B C$ and $S F-B C$, as well as increased the survival of bacterial cultures treated with stannous chloride. Our results suggest that reishi extract could present a redox/chelating action, altering the labeling of blood constituents with ${ }^{99 m} T c$ and protecting bacterial cultures against oxidative damage induced by stannous chloride.
\end{abstract}

Keywords: blood constituents, Escherichia coli, Ganoderma lucidum, stannous chloride, technetium-99m

\section{INTRODUCTION}

Ganoderma lucidum (reishi) is a traditional chinese medicine product known to the layman as the "herb of immortality". It has been used as a health tonic to promote longevity for more than two thousand years. Reishi extract contains two major groups of bioactive polysaccharide and triterpene components (Bao et al., 2002). These compounds in reishi have been studied due to their potential immunomodulating activity and antitumor effect, as demonstrated in both in vitro and in vivo models (Lin et al., 2004).

Pharmacological effects and physiological properties of reishi include immune enhancement, maintenance of homeostasis and regulation of

\footnotetext{
Author for correspondence
} 
biorhythm, and prevention of and improvement against some diseases, including cancer, cerebral stroke and heart disease (Lin et al., 2004). Other authors have suggested antifungal, antiinflammatory, antitumor, antiviral, antibacterial, hepatoprotective, antidiabetic, hypolipedemic, antithrombotic and hypotensive activities for reishi (Ajith et al., 2007).

Red blood cells labeled with technetium-99m $\left.{ }^{99 \mathrm{~m}} \mathrm{Tc}-\mathrm{RBC}\right)$ are used in clinical nuclear medicine for diagnostic evaluations (Verdu et al., 2005; Olds et al., 2005). Thus, the labeling of RBC with ${ }^{99 \mathrm{~m}} \mathrm{Tc}$ has been also used as an assay to investigate the properties of different chemical agents (Fonseca et al., 2007). This radiolabeling depends on the presence of a reducing agent and stannous chloride has being widely utilized (Saha, 2004).

Although, the stannous ion has clinical utilization, some authors have suggested that stannous chloride appears to induce lesions in the deoxyribonucleic acid (DNA) by oxidative mechanisms related to free radical generation (ElDemerdash et al., 2005; Presta et al., 2007), which could result in cell inactivation or potentially tumorigenesis and protection against this effect would be of particular interest in nuclear medicine, where stannous chloride is used for the preparation of radiopharmaceuticals (Saha, 2004).

Thus, the aim of this work study was to verify the effects of an extract of reishi on the labeling of blood constituents with ${ }^{99 \mathrm{~m}} \mathrm{Tc}$ and on the survival of Escherichia coli cultures treated with stannous chloride.

\section{MATERIALS AND METHODS}

\section{Extract preparation}

Ganoderma lucidum (GL) (0,35 g) (SKL Herbal Científica Laboratório Farmacêutico Ltda., lot number 201221, validity November 2008). The extract of reishi was prepared with $0.35 \mathrm{~g}$ of a purified powder in $100 \mathrm{~mL}$ of $0.9 \% \mathrm{NaCl}$ (saline). The preparation was homogenized in a vortex mixer and centrifuged (2000 rpm, 10 minutes). The supernatant was collected and considered to be $3.5 \mathrm{mg} / \mathrm{mL}$.

\section{Spectrophotometric measurements}

Spectrophotometric analysis (TV-VIS Spectrophotometer Beijing Purkinje General Instrument Co., Ltd, Beijing, People's Republic of China) of the extract at $3.5 \mathrm{mg} / \mathrm{ml}$ was carried out.
An absorption peak $(0.56 \pm 0.01)$ was obtained at $255 \mathrm{~nm}$ and it was used as a marker of reproducibility preparation of this extract.

\section{Animals}

Wistar rats $(\mathrm{n}=12,3-4$ months, $245 \pm 35 \mathrm{~g})$ were kept under controlled environmental conditions $\left(25 \pm 2^{\circ} \mathrm{C}, 12 \mathrm{~h}\right.$ of light/dark cycle), water and libitum and normal diet. Heparinized whole blood was withdrawn by cardiac puncture from animals under anesthesia by sodium thiopental $(40 \mathrm{mg} / \mathrm{kg})$. All the experimental procedures followed the Ethical Guidelines of the Instituto de Biologia Roberto Alcantra Gomes, Universidade do Estado do Rio de Janeiro with the protocol number CEA/ $115 / 2006$.

\section{Labeling of blood constituents with ${ }^{99 \mathrm{~m}} \mathrm{Tc}$} Blood samples $(\mathrm{n}=8$, for each extract concentration) of whole blood were incubated with reishi extract $(0.0,0.2,0.4,0.85,1.75$ and $3.5 \mathrm{mg} / \mathrm{mL}, 1$ hour). After that, a freshly prepared stannous chloride solution $\left(\mathrm{SnCl}_{2}, 1.2 \mu \mathrm{g} / \mathrm{ml}\right.$, Sigma Chemical Co. St Louis, USA, 1 hour) was added. Then, ${ }^{99 \mathrm{~m}} \mathrm{Tc}$ (3.7 MBq, 10 minutes) was added. These samples were centrifuged $(1500 \mathrm{rpm}$, 5 minutes) and plasma (P) and blood cells (BC) were separated. Aliquots of $\mathrm{P}$ and $\mathrm{BC}$ were also precipitated in trichloroacetic acid (5\%) and soluble (SF) and insoluble (IF) fractions were obtained. Radioactivity (\%ATI) in P, BC, IF-P, SF-P, IF-BC and SF-BC was determined in a well gamma counter (Clinigamma, gamma counter, Packard, Instrument Company, mod C5002, USA). The percentage of incorporated radioactivity (\%ATI) was calculated as previously described (Bernardo Filho et al., 1983). The data were expressed as mean \pm standard deviation of \%ATI. The values were analyzed by one-way variance analysis (ANOVA) with a $p<0.05$ as significant level followed by Bonferroni post-test.

\section{Bacterial inactivation}

E. coli AB1157, a wild-type strain, proficient in repairing DNA damage, was used in this work. From stock (in glycerol 50\% v/v), an aliquot was grown in liquid LB (Luria and Burrous, 1957) medium at $37^{\circ} \mathrm{C}$ overnight up to stationary growth phase. An aliquot was taken from this culture and further incubated under the same conditions to reach exponential growth $\left(10^{8}\right.$ cells $\left./ \mathrm{mL}\right)$. The cells were collected by centrifugation, washed twice in saline and suspended again in saline. After that, 
bacterial suspensions $\left(10^{8}\right.$ cells $\left./ \mathrm{mL}\right)$ were treated with stannous chloride $(25 \mu \mathrm{g} / \mathrm{mL})$ in the presence or absence of reishi extract $(1.75$ and $3.5 \mathrm{mg} / \mathrm{mL})$ for 60 minutes. Aliquots from these treatments were diluted in saline, spread onto Petri dishes containing solidified LB medium (1.5\% agar). Colonies formed after overnight incubation at 37 ${ }^{\circ} \mathrm{C}$ were counted and the survival fraction was calculated as described before (Almeida et al., 2007). Experiments were carried out in triplicate and the results presented are the average mean of three independent assays.

\section{RESULTS}

Table 1 presents the \%ATI of the plasma and blood cells from blood samples treated with reishi extract. These data suggest that reishi extract at the highest concentrations used (1.75 and $3.5 \mathrm{mg} / \mathrm{mL}$ ) alters the distribution of radioactivity between plasma and cellular components.

Table 1 - Effect of the treatment with reishi extract on the distribution of radioactivity between plasma and cellular compartments.

\begin{tabular}{|c|c|c|}
\hline \multirow[t]{2}{*}{$\begin{array}{c}\text { Ganoderma } \\
(\mathrm{mg} / \mathrm{mL})\end{array}$} & \multicolumn{2}{|c|}{$\%$ ATI } \\
\hline & $\mathbf{P}$ & BC \\
\hline 0.0 & $7.18 \pm 0.93$ & $92.82 \pm 0.93$ \\
\hline 0.2 & $6.17 \pm 5.33$ & $93.83 \pm 5.33$ \\
\hline 0.4 & $2.56 \pm 1.39$ & $97.44 \pm 1.49$ \\
\hline 0.85 & $2.91 \pm 0.86$ & $97.09 \pm 0.86$ \\
\hline 1.75 & $41.75 \pm 3.76 *$ & $58.25 \pm 3.76 *$ \\
\hline 3.5 & $54.89 \pm 1.82 *$ & $45.11 \pm 1.82 *$ \\
\hline
\end{tabular}

(*) $p<0.05$ when compared with control.

Table 2 presents the \%ATI of the insoluble and soluble fractions of plasma. Data suggest that reishi extract treatment at highest concentrations
$(0.85,1.75$ and $3.5 \mathrm{mg} / \mathrm{mL})$ also alters the fixation of radioactivity on plasma proteins.

Table 2 - Effect of reishi extract on the fixation of radiactivity on plasma fractions.

\begin{tabular}{ccc}
\hline $\begin{array}{c}\text { Ganoderma } \\
(\mathbf{m g} / \mathbf{m L})\end{array}$ & \multicolumn{3}{c}{ \% ATI } \\
\cline { 2 - 3 } & IF-P & SF-P \\
\hline 0.0 & $67.89 \pm 4.35$ & $32.11 \pm 4.35$ \\
0.2 & $64.52 \pm 4.04$ & $35.48 \pm 4.04$ \\
0.4 & $68.68 \pm 3.85$ & $31.32 \pm 3.85$ \\
0.85 & $53.85 \pm 2.20 *$ & $46.15 \pm 2.20 *$ \\
1.75 & $14.15 \pm 8.60 *$ & $85.85 \pm 8.60 *$ \\
3.5 & $6.30 \pm 0.48 *$ & $93.70 \pm 0.48 *$ \\
\hline
\end{tabular}

Insoluble fraction of the plasma (IF-P), soluble fraction of the plasma (SF-P). $(*) p<0.05$ when compared with control.

Table 3 presents the \%ATI of the insoluble and soluble fractions of blood cells. Data suggest that reishi extract treatment at the higher concentration $(3.5 \mathrm{mg} / \mathrm{mL})$ alters the fixation of radioactivity on cellular proteins.

Figure 1 shows the survival fractions of E. coli $\mathrm{AB} 1157$ cultures treated with $\mathrm{SnCl}_{2}$ in the presence and absence of reishi extract, demonstrating that reishi offers protection from free radicals generated by stannous chloride.

Data in figure 1 suggest that the treatment with reishi extract would not present cytotoxic effects on $E$. coli AB1157 cell cultures, in the absence of stannous chloride, but would increase the survival of these cultures treated with stannous chloride, particularly at the higher dose. 
Table 3 - Effect of reishi extract on the fixation of radiactivity on blood cell fractions.

\begin{tabular}{ccc}
\hline $\begin{array}{c}\text { Ganoderma } \\
(\mathbf{m g} / \mathbf{m L})\end{array}$ & \% ATI & \\
\hline & IF-BC & SF-BC \\
\hline 0.0 & $89.85 \pm 2.81$ & $10.15 \pm 2.81$ \\
0.2 & $89.27 \pm 7.74$ & $10.73 \pm 7.74$ \\
0.4 & $93.03 \pm 1.73$ & $6.97 \pm 1.73$ \\
0.85 & $89.97 \pm 4.34$ & $10.03 \pm 4.34$ \\
1.75 & $74.19 \pm 10.40$ & $25.81 \pm 10.40$ \\
3.5 & $26.30 \pm 0.53 *$ & $73.70 \pm 0.53 *$ \\
\hline
\end{tabular}

Insoluble fraction of the blood cells (IF-BC), soluble fractions of the blood cells (SF-BC). $\left(^{*}\right) p<0.05$ when compared with control.

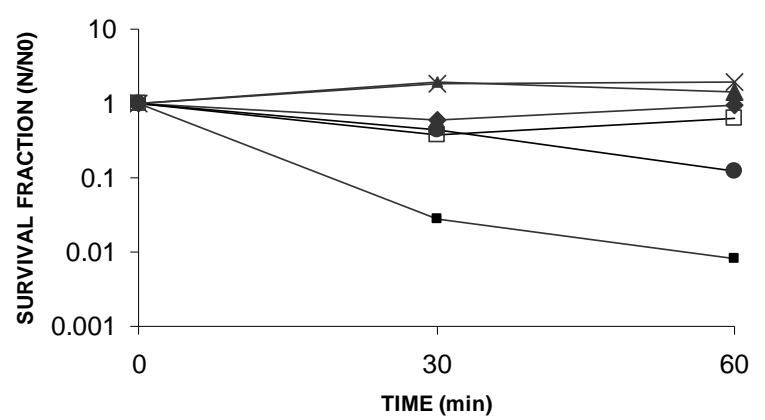

Figure 1 - Survival fractions of E. coli AB1157 cultures treated with stannous chloride in the presence and absence of reishi extract. E. coli $\mathrm{AB} 1157$ cultures were treated with stannous chloride $\left(\mathrm{SnCl}_{2}, 25 \mu \mathrm{g} / \mathrm{mL}\right)$ in presence and absence of reishi extract (17.5 and $35 \mathrm{mg} / \mathrm{mL}$ ), aliquots were diluted in saline and spread onto Petri dishes. After overnight incubation $\left(37{ }^{\circ} \mathrm{C}\right)$, colony forming units were counted to determine

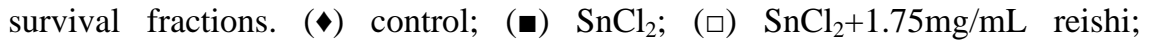
$\mathrm{SnCl}_{2}+3.5 \mathrm{mg} / \mathrm{mL}$ reishi; $(\times)$ reishi extract $1.75 \mathrm{mg} / \mathrm{mL} ;(\boldsymbol{\Delta})$ reishi extract $3.5 \mathrm{mg} / \mathrm{mL}$.

\section{DISCUSSION}

There is evidence that natural drugs could affect the radiolabeling of blood constituents, and these findings have been considered in the development of this procedure as an experimental model to verify the properties of these drugs (Benarroz et al., 2008; Frydman et al., 2008).

The analysis of tables 1,2 and 3 indicates that there was an important alteration on the radiolabeling of the blood constituents from blood samples treated with reishi extract. It is interesting to note that although in the absence of reishi nearly $93 \%$ of ATI was in the cellular component, this shifted to almost equal distribution between on plasma and blood cells compartments at high reishi concentrations. Furthermore, there was a shift in the labeling of soluble and insoluble fractions, where the \%ATI in the insoluble fractions changed from nearly $70 \%$ to less than $7 \%$, with a corresponding increase of labeling in the soluble fractions. The pattern was similar in the labeling of the cellular component, with a shift of the highest labeling (expressed as \%ATI) from the insoluble towards the soluble fractions.

Previous studies have demonstrated that reishi extracts act on humoral immune response (Bao et al., 2002; Lin et al., 2005) and a polysaccharide isolated from reishi has been shown to increase the response to sheep RBC in mice (Lin et al., 2004). In vitro, reishi polysaccharides also increased lymphocyte proliferation (Cao et al., 2003). Radiolabeling data obtained in this study could be related to actions of reishi polysaccharides on 
blood constituents. Another possibility is the redox/chelating action of the substances in reishi extract. In fact, some natural products could alter the labeling of blood constituents with ${ }^{99 \mathrm{~m}} \mathrm{Tc}$ by interfering on the reducing action of the $\mathrm{SnCl}_{2}$ (Benarroz et al., 2008).

To verify this hypothesis, effects of reishi extract on E. coli $\mathrm{AB} 1157$ treated with $\mathrm{SnCl}_{2}$ were evaluated (Figure 1). Our data suggest that the extract used could protect $E$. coli cells against the oxidative effect of $\mathrm{SnCl}_{2}$ and indicate that chemical compounds in reishi extract present redox/chelating activity. In addition, data obtained with bacterial cultures treated with reishi in the absence of stannous chloride indicate an absence of antibacterial action of the reishi extract used. Similar findings were obtained with an extract of cauliflower (Lima et al., 2002).

In conclusion, results obtained in this work suggest that reishi extract has redox/chelating properties, altering the labeling of blood constituents with ${ }^{99 \mathrm{~m}} \mathrm{Tc}$ and protecting bacterial cultures against oxidative damage induced by stannous chloride.

\section{ACKNOWLEDGMENTS}

This research was supported by Fundação de Amparo a Pesquisa do Estado do Rio de Janeiro (FAPERJ), Conselho Nacional de Desenvolvimento Científico e Tecnológico (CNPq), Universidade do Estado do Rio de Janeiro (UERJ) and The Open University (OU).

\section{RESUMO}

Este estudo avaliou efeitos de um extrato de Ganoderma lucidum (reishi) na marcação de constituintes sangüíneos com tecnécio-99m $\left({ }^{99 m} \mathrm{Tc}\right)$ e na sobrevivência de culturas de Escherichia coli tratadas com cloreto estanoso. Amostras de sangue de ratos Wistar foram tratadas com extrato de reishi, o procedimento de radiomarcação foi realizado, plasma $(\mathrm{P})$, células sangüíneas (CS) e frações insolúvel (FI) e solúvel (FS) de P e CS foram separadas e a radioatividade foi contada para determinação das porcentagens de radioatividade (\%ATI). Culturas de Escherichia coli $\mathrm{AB} 1157$ foram tratadas com cloreto estanoso na presença e ausência do extrato de reishi.
Amostras de sangue e culturas bacterianas tratadas com $\mathrm{NaCl} 0.9 \%$ foram usadas como controles. Dados indicaram que o extrato de reishi alterou significativamente $(p<0,05)$ a \%ATI de P, CS, FIP, FS-P, FI-CS e FS-CS, bem como, aumentou a sobrevivência de culturas bacterianas tratadas com cloreto estanoso. Nossos resultados sugerem que o extrato de reishi poderia apresentar ação redox/quelante alterando a marcação de constituintes sangüíneos com ${ }^{99 \mathrm{~m}} \mathrm{Tc}$ e protegendo culturas bacterianas contra lesões oxidativas induzidas pelo cloreto estanoso.

\section{REFERENCES}

Ajith, T. A. (2007), 2007 and Kainoor K. Janardhanan Indian Medicinal Mushrooms as a Source of Antioxidant and Antitumor Agents. J Clin Biochem Nutr., 40, 157-162.

Almeida, M. C.; Soares, S. F.; Abreu, P. R.; Jesus, L. M.; Brito, L. C.; Bernardo-Filho, M. (2007), Protective effect of an aqueous extract of. Harpagophytum procumbens upon Escherichia coli strains submitted to the lethal action of stannous chloride. Cell Mol Biol (Noisy-le-grand), 53, 923927.

Bao, X. F.; Wang, X. S.; Dong, Q.; Fang, J. N.; Li, X...Y. (2002), Structural features of immunologically active polysaccharides from Ganoderma lucidum. Phytochemistry, 59, 175-181.

Benarroz, M. O.; Fonseca, A. S.; Rocha, G. S.; Frydman, J. N.; Rocha, V. C.; Pereira, M. O.; Bernardo-Filho, M. (2008), Cinnamomum zeylanicum extract on the radiolabelling of blood constituents and the morphometry of red blood cells: In vitro assay. Appl Radiat Isot., 66, 139-146.

Bernardo-Filho, M.; Moura, I.; Boasquevisque, E. (1983), 99mtechnetium-labeled red blood cells "in vitro". Arq BiolTecnol., 26, 455-461.

Cao, L. Z.; Lin, Z. B. (2003), Comparison of the effects of polysaccharides from wood-cultured and bagcultured Ganoderma lucidum on murine spleen lymphocyte proliferation in vitro. Acta Pharm Sin., 38, 92-97.

El-Demerdash, F. M.; Yousef, M. I.; Zoheir, M. A. (2005), Stannous chloride induces alterations in enzyme activities, lipid peroxidation and histopathology in male rabbit: antioxidant role of vitamin C. Food Chem Toxicol., 43, 1743-1752.

Fonseca, A. S.; Frydman, J. N.; Rocha, V. C.; Bernardo-Filho, M. (2007), Acetylsalicylic acid decreases the labeling of blood constituents with technetium-99m. Acta Biol Hung., 58, 187-198. 
Frydman, J. N. G.; Rocha, V. C.; Benarroz, M. O.; Rocha, G. S.; Pereira, M. O.; Fonseca, A. S.; Bernardo-Filho, M. (2008a), Assessment of effects of a Cordia salicifolia extract on the radiolabeling of blood constituents and on the morphology of red blood cells. J Med Food, in press.

Lima, E. A.; Diré, G.; Mattos; D. M.; Freitas, R. S.; Gomes, M. L.; de Oliveira, M. B.; Faria, M. V.; Jales, R. L.; Bernardo-Filho, M. (2002), Effect of an extract of cauliflower (leaf) on the labeling of blood elements with technetium-99m and on the survival of Escherichia coli AB1157 submitted to the treatment with stannous chloride. Food Chem Toxicol., 40, 919923.

Lin, Z. B. (2005), Cellular and molecular mechanisms of immuno-modulation by Ganoderma lucidum. $J$ Pharmacol Sci., 99, 144-153.

Lin, Z. B.; Zhang, H. N. (2004), Anti-tumor and immunoregulatory activities of Ganoderma lucidum and its possible mechanisms. Acta Pharmacol Sin., 25, 1387-1395.

Luria, S. E.; Burrous, J. W. (1957), Hybridization between E. coli and Shigella. J Bacteriol., 74, 461476.
Olds, G. D.; Cooper, G. S.; Chak, A.; Sivak, M. V. J.; Chitale, A. A.; Wong, R. C. (2005), The yield of bleeding scans in acute lower gastrointestinalhemorrhage. J Clin Gastroenterol., 39, 273-277.

Presta, G. A.; Fonseca, A. S.; Bernardo-Filho, Mario. (2007), A Chrysobalanus icaco extract alters the plasmid topology and the effects of stannous chloride on the DNA of plasmids. Rev Bras Farmacogn., 17, 331-335

Saha, G. B. (2004), Fudamentals of nuclear pharmacy. Springer Verlag, New York.

Verdu, J.; Martinez, A.; Anton, M. A.; Munozm J. M.; Riera, M.; Jover, R.; Caballero, O. (2005), Increased thallium-201 uptake and Tc-99m red blood cell accumulation in hemangioma. Clin Nucl Med., 30, 25-26.

Received: August 26, 2008; Revised: September 11, 2008; Accepted: September 15, 2008. 